\title{
Farmland biodiversity: wildflower-sown islands within arable fields and grassy field margins both promote spider diversity
}

\author{
Tamara Rischen $^{1}$ (D) $\cdot$ Katharina Geisbüsch ${ }^{1} \cdot$ Daniel Ruppert $^{1} \cdot$ Klaus Fischer $^{1}$
}

Received: 6 July 2021 / Accepted: 25 November 2021 / Published online: 3 December 2021

(c) The Author(s) 2021

\begin{abstract}
Agricultural intensification and the concomitant landscape homogenization is leading to a worldwide decline in farmland biodiversity. Non-crop habitats in agroecosystems may counteract the loss of arthropods such as spiders and thus contribute to sustainable agriculture. However, the effectiveness of field margins and set-aside wildflower-sown patches in maintaining spider diversity is not well understood. Here, we investigated the effects of three different non-crop habitats, namely field margins, set-aside wildflower-sown patches under power poles ('power pole islands'), and grassland fallows on spider diversity as compared to wheat fields in an agricultural landscape in western Germany. Using pitfall trapping and suction sampling, we show that species richness and overall conservation value were higher in non-crop habitats than in wheat fields. Interestingly, field margins and power pole islands differed from long-term grassland fallows only in conservation value, which was significantly higher in grassland fallows. Species assemblages differed considerably between grassland fallows, field margins and power pole islands, and wheat fields, documenting the added value of using different conservation strategies. Implications for insect conservation Small-scale non-crop habitats adjacent to wheat fields were surprisingly effective in promoting spider diversity in an agricultural landscape, with field margins and power pole islands being equally effective. To maximize overall diversity in agricultural landscapes, we propose a combination of larger long-term fallows and smaller non-crop habitats such as field margins or set-aside wildflower-sown patches.
\end{abstract}

Keywords Agriculture $\cdot$ Biodiversity conservation $\cdot$ Body size $\cdot$ Non-crop habitat $\cdot$ Pitfall trapping $\cdot$ Suction sampling

\section{Introduction}

Though agriculture is essential for providing food and other resources to an ever-growing human population, intensification of land use is considered to be one of the main causes of global biodiversity loss (Donald et al. 2001; Benton et al. 2002; Seibold et al. 2019). Increasing mechanization and the demand for higher crop yields have led to a simplification of agricultural landscapes by enlarging field sizes and reducing crop types, and to the widespread use of fertilizer and pesticides (Tscharntke et al. 2005; Tryjanowski et al. 2011). In parallel, the proportion of semi-natural landscape elements, which are important for protecting biodiversity, has decreased in agricultural landscapes (Billeter et al. 2008;

Tamara Rischen

tamararischen@uni-koblenz.de

1 Department Biology, Institute of Integrated Natural Sciences, Koblenz-Landau University, Universitätsstraße 1, 56070 Koblenz, Germany
Fahrig et al. 2011). The frequent disturbance on cropland, e.g. due to the application of agrochemicals and tillage, has detrimental effects on farmland biodiversity (Thorbek and Bilde 2004; Batáry et al. 2008, 2012). Thus, intensively used crop fields are unsuitable for many organisms, and agricultural intensification comprises a major driver of biodiversity loss in industrialized countries (Donald et al. 2001; Kleijn et al. 2009).

To counteract the widespread decline of biodiversity in agricultural landscapes, a wide variety of measures has been applied in recent decades, some of which aim to increase landscape heterogeneity, an important driver of species richness (Benton et al. 2003; Fahrig et al. 2011). Especially for habitat specialists, the size and spatial configuration of noncrop habitats are important determinants for the maintenance of viable populations (Öberg et al. 2007; Pluess et al. 2010; Knapp and Řezáč 2015; Šálek et al. 2018). Only heterogeneous landscapes, composed of arable fields and adjacent non-crop habitats, may offer essential features such as hibernation and feeding places, refuges, and dispersal corridors 
(Pfiffner and Luka 2000; Sunderland and Samu 2000; Östman et al. 2001).

Semi-natural habitats, e.g. long-term grassland fallows, are also important for the conservation of plant, arthropod and bird species in agricultural landscapes (e.g. Benton et al. 2003; Hendrickx et al. 2007; Rischen et al. 2021). They typically show a more complex vegetation structure, more stable conditions, and more variable soil moisture compared with the surrounding crop fields (Plath et al. 2021). Other non-crop habitats such as grassy field margins and set-aside fields, can link isolated fragments of semi-natural habitats and contribute to landscape heterogeneity (Critchley et al. 2004; Kovács-Hostyánszki et al. 2011; Morris et al. 2011). In general, non-crop habitats provide refuges for arthropods during field manipulations (Schmidt-Entling and Döbeli 2009), and contribute to the conservation of generalist predators such as beetles and spiders in agricultural landscapes (Frank et al. 2012; Plath et al. 2021). Overall, the conservation and restoration of non-crop habitats is thus one of the most effective conservation measures in intensively managed agricultural landscapes (Tscharntke et al. 2002; Knapp and Řezáč 2015). Therefore, agri-environmental schemes within the European Union's Common Agricultural Policy (CAP) aim to promote such habitats in agroecosystems (Holland et al. 2017). These include, among others, fields margins and set-aside crop fields subsequently sown with wildflowers (Van Buskirk and Willi 2004; Haaland et al. 2011; Plath et al. 2021).

While various greening measures are applied in agricultural landscapes, best practises for promoting spider diversity are not resolved (Mestre et al. 2018; Ganser et al. 2019). Spiders are one of the most abundant and diverse invertebrate groups in agricultural landscapes, and contribute to ecosystem services by feeding on pests (Symondson et al. 2002; Michalko et al. 2019). In particular, so-called 'agrobionts', i.e. spider species thriving in agricultural landscapes, can be dominant natural enemies (Luczak 1979; Samu and Szinetár 2002). Even for agrobionts non-crop habitats can be important, for example as overwintering sites (SchmidtEntling and Döbeli 2009). More specialised spider species may be restricted to certain habitat types, such that spider assemblages may differ between non-crop habitats (Nardi et al. 2019). Moreover, landscape and habitat features may influence the functional diversity of spider communities (e.g. body size, occurrence of ecotypes, preference for specific strata; Schirmel et al. 2016; Gallé et al. 2018). For example, body size may be related to land-use intensity, with smaller body size being associated with more disturbed habitats (Schirmel et al. 2016; Plath et al. 2021). In addition, body size and habitat preference can serve as indicators of the extent of ecosystem services provided by spiders in agricultural landscapes (Rusch et al. 2015). For evidence-based conservation recommendations, it is hence necessary to investigate the effectiveness and conservation potential of different non-crop habitats for spiders in agroecosystems (e.g. Košulič et al. 2014). While the impact of field margins on spiders has been addressed in several studies (e.g. Huusela-Veistola 1998; Gallé et al. 2018; Zhang et al. 2020), the effectiveness of set-aside wildflower-sown fields for spider conservation is largely unclear.

We here compare the effectiveness of three non-crop habitat types, namely long-term grassland fallows, field margins, and wildflower-sown patches under power poles ('power pole islands'), in relation to wheat fields for promoting spider diversity in an agricultural landscape in western Germany. More specifically, we compare spider taxonomic species richness and diversity, community structure, and functional diversity between these habitat types. We predicted that, due to the lower management intensity, (1) species richness and diversity of spiders are higher on power pole islands and field margins than on wheat fields, but lower than on grassland fallows with their larger patch size (see Bonte et al. 2002). Since the occurrence of spiders is related to the availability of appropriate environmental niches (Michalko and Birkhofer 2021), we furthermore predicted that (2) wheat fields have a higher proportion of xerophilous and euryoecious spiders compared to non-crop habitats due to their dry and disturbed conditions. Finally, we predicted that (3) grassland fallows exhibit the highest proportion of hygrophilous spider species, while field margins and power pole islands harbour more agrobionts, as edge effects may favour their immigration due to their small area and proximity to wheat fields (Samu and Szinetár 2002; Blitzer et al. 2012). Consequently, we expected differences in community structure between habitat types, allowing us to explore which combination of habitats enhances overall spider diversity the most in an agricultural landscape.

\section{Materials and methods}

\section{Study area}

The study was conducted in an intensively used agricultural landscape dominated by crop fields within the Eifel mountain range in western Germany $\left(50^{\circ} 14^{\prime} \mathrm{N}, 7^{\circ} 21^{\prime} \mathrm{E}\right.$; Fig. 1). The study area belongs to the 'Maifeld' region, characterized by an oceanic climate with a precipitation of $\sim 598 \mathrm{~mm} /$ year and a mean annual temperature of $\sim 10{ }^{\circ} \mathrm{C}$ (Agrarmeteorologie Rheinland-Pfalz 2020). To a small extent, non-crop habitats, for example, grassland fallows, field margins, and set-aside areas sown with wildflower mixtures occur. Agricultural lands comprised $72.2 \%$, forests $11.8 \%$, and settlement and traffic areas 13.9\% of the Maifeld in 2018 (Statistisches Landesamt Rheinland-Pfalz 2018). To evaluate the effects of land use on spider assemblages, we investigated 


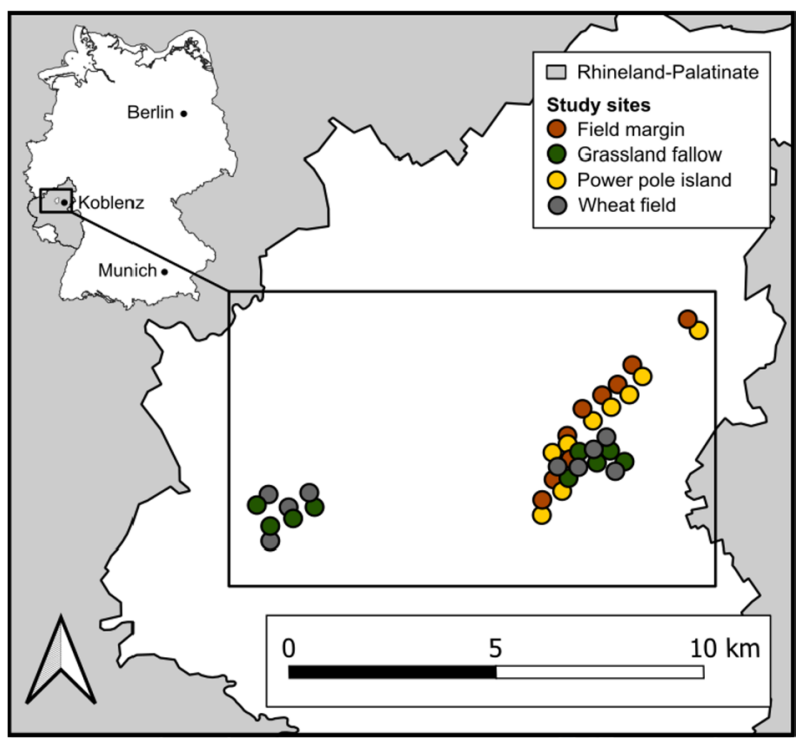

Fig. 1 Location of the study area near the city of Koblenz within Germany and of the study sites (enlarged) within the 'Maifeld'

four habitat types with nine replicate plots each (total $n=36$; Fig. 1; Table A1, Supplementary Material): (1) wheat fields sown with Triticum aestivum (conventional management with fertilizing, fungicide and herbicide spraying), (2) grassy field margins bordering wheat fields (mown once during sampling), (3) set-aside habitat islands under power poles ( 2 years old fallows under poles of a power line, sown with a mixture of wildflower seeds as 'greening' measure, $12 \times 12 \mathrm{~m}$; hereafter: 'power pole islands'), and (4) grassland fallows (unmanaged long-term grassland fallows with a diverse natural vegetation cover, formerly used as meadows but abandoned decades ago). Limiting factors for our comparisons were the availability of grassland fallows (being rare in the study area) and power pole islands (only found along a power line). Therefore, we 'clustered' our sampling plots somewhat, by always choosing a wheat field close to a grassland fallow, and a field margin close to a power pole island (Fig. 1).

\section{Sampling methods}

We collected spiders between the 15 th of April and the 7 th of July 2020 using two complementary methods, pitfall trapping and suction sampling. For pitfall trapping, we used two PET cups $(\varnothing=5.6 \mathrm{~cm}$, volume $125 \mathrm{ml}$, filled with $70 \%$ water and $30 \%$ monopropylene glycol) per replicate plot as traps ( 4 habitat types $\times 9$ locations $\times 2$ traps). Pitfall traps were covered by a plastic roof for protection and buried into the ground, $5 \mathrm{~m}$ apart. In field margins and in power pole islands, pitfall traps were centrally located, while in wheat fields and grassland fallows they were set up in a distance of
$30 \mathrm{~m}$ from the edge. Traps were emptied every 2 weeks (i.e. a total of six times), with the number of trapping days ranging between 82 and 83 days per plot. Samples were stored in $70 \%$ ethanol for later identification. Suction sampling was performed on the same plots using a leaf blower (Stihl SH 56, Dieburg, Germany) with a polyamide stocking attached to the front of the nozzle. Each plot was sampled twice on dry days in May and June 2020, 2 weeks apart. Each sampling unit consisted of suctioning the vegetation along a $5 \mathrm{~m}$ transect (i.e. between both pitfall traps), inserting the nozzle into the vegetation ten times for $7 \mathrm{~s}$ each (Brook et al. 2008). Samples were transferred to plastic bags, frozen at $-18^{\circ} \mathrm{C}$, and then stored in $70 \%$ ethanol. All adult spiders captured were identified to the species level using taxonomic keys (Roberts 1987, 1995; Nentwig et al. 2020).

\section{Data analyses}

Data from pitfall trapping and suction sampling were pooled for subsequent analyses. For each plot, we calculated the total numbers of species and individuals (although pitfall trapping gives data on activity density only, we here use 'individual number' because of the inclusion of the individuals from suction sampling), the effective number of species, which is a derivate of the Shannon-Wiener index and represents the actual diversity (Jost 2006), and the 'conservation value' according to Görn and Fischer (2011). The latter was determined by assigning a point score to each species according to its German red list status (Blick et al. 2016; Table A2, Supplementary Material): least concern = 1 point, near-threatened $=5$ points, risk assumed $=10$ points, vulnerable $=15$ points. We also estimated the sample coverage for each plot to account for differences in detection probability between the four habitat types. Therefore, we calculated the rarefied species richness for a sample coverage of $90 \%$ using the iNEXT package (Hsieh et al. 2020) in R 4.0.5 (R Core Team 2020). The body size of each species was determined by using the mean value available in Nentwig et al. (2020). Afterwards, we calculated community weighted mean (CWM) values by weighing the respective body size by each species' relative abundance (Ricotta and Moretti 2011). Platen et al. (1991) and Platen and Broen (2005) were used to assign each species to an ecotype (hygrophilous, mostly hygrophilous, euryoecious, xerophilous species) and the preferred stratum (ground-dwelling, herb layer, taller vegetation). For all subsequent analyses, we standardized the above data by giving the respective proportion per plot.

\section{Statistical analyses}

To test for the effect of habitat type on the numbers of species, individuals, and rarefied species, on the effective number of species, conservation value, CWM body size, 
and the number of individuals of the most common species (dependent variables), one-way ANOVAs were used followed by Tukey HSD posthoc tests to locate significant differences. To meet ANOVA requirements, the values for the number of individuals were $\mathrm{LN}$-transformed and for the numbers of individuals of the four most common species were $\mathrm{LN}+1$ transformed prior to analyses. We used Moran's I tests (ape-package in R; Paradis and Schliep 2019) to test for spatial autocorrelation of all dependent variables and their residuals (Dormann et al. 2007), being non-significant throughout. We also calculated Moran's I tests only with the 'clustered' habitat types (group 1: wheat fields and grassland fallows; group 2: field margins and power pole islands). Furthermore, we tested for differences in spider community composition across the four habitat types based on Bray-Curtis indices derived from the relative abundance of species. We used permutational multivariate analyses of variance (PERMANOVAs, with 999 permutations), visualised by nonmetric multidimensional scaling (NMDS). In addition, PERMANOVAs (999 permutations) were used to test for significant differences in the proportion of species with specific ecotypes or stratum preferences between habitat types. We also performed pairwise PERMANOVAs to locate significant differences among habitat types. Statistical analyses were performed with Statistica 12.0 (Tulsa, StatSoft) or using the vegan package in R 4.0.5 (R Core Team 2020; Oksanen et al. 2020).

\section{Results}

In total, 4942 adult spiders belonging to 112 species and 18 families were collected. Pitfall trapping yielded 4407 spiders belonging to 91 species, and suction sampling yielded 535 spiders belonging to 63 species (Table A2, Supplementary Material). Overall, most individuals belonged to the families Linyphiidae (30\% of all individuals), Lycosidae (16\%), Gnaphosidae (11\%), Thomisidae (8\%), Theridiidae (7\%), and Salticidae (4\%). Five of the above six most common spider families showed the lowest numbers of individuals in wheat fields (Table A3, Supplementary Material), while the number of Linyphiidae was highest in wheat fields. Of the 112 spider species captured, 49 species were exclusively caught by pitfall trapping, 21 exclusively by suction sampling, and 42 species by both methods, with patterns being roughly similar across habitat types (Fig. A1, Supplementary Material). Both, pitfall trapping and suction sampling identified the highest shares of all species in grassland fallows and the lowest ones in wheat fields (Fig. A2, Supplementary Material). Only four of the species found are included in the red list of Germany as near threatened (2), risk assumed (1), or vulnerable (1; Table A2, Supplementary Material).

Habitat type significantly affected the number of species $\left(F_{3,32}=8.14, p<0.001\right)$, the number of rarefied species $\left(F_{3,32}=5.45, p<0.01\right)$, the effective number of species $\left(\mathrm{F}_{3,32}=4.08, \mathrm{p}=0.015\right)$, the conservation value $\left(\mathrm{F}_{3,32}=12.78, \mathrm{p}<0.0001\right)$, and the CWM body size $\left(\mathrm{F}_{3,32}=3.51, \mathrm{p}=0.026\right)$, but not the number of individuals $\left(F_{3,32}=1.95, p=0.142\right.$; Fig. 2$)$. Differences between noncrop habitats in the above parameters were non-significant throughout, apart from the conservation value, which was significantly higher for grassland fallows than for field margins or power pole islands. Wheat fields, in contrast, differed significantly from non-crop habitats except from field margins and power pole islands for the number of rarefied species, grassland fallows for the effective species number, and field margins and grassland fallows for CWM body size (Fig. 2).

Spider assemblage structure differed significantly between habitat types (PERMANOVA: $\mathrm{F}_{3,32}=3.02$, $\mathrm{p}=0.001, \mathrm{R}^{2}=0.22$, Fig. 3 ). There were significant differences between all habitat types, except for field margins and power pole islands (PERMANOVA, pairwise comparisons). The strongest separation was found between the assemblages of wheat fields and grassland fallows. Furthermore, the proportions of ecotypes and stratum preferences showed significant differences between habitat types (PERMANOVAs; ecotypes: $\mathrm{F}_{3,32}=3.46, \mathrm{p}=0.006, \mathrm{R}^{2}=0.25$; strata: $\mathrm{F}_{3,32}=5.01, \mathrm{p}=0.007, \mathrm{R}^{2}=0.32$ ). Wheat fields and field margins differed significantly from grassland fallows in the proportions of ecotypes, while power pole islands did not differ from any other habitat type (Fig. 4a). Grassland fallows were characterized by high proportions of hygrophilous and mostly hygrophilous species and a relatively low proportion of euryoecious species. In terms of stratum preference, wheat fields and field margins differed significantly from power pole islands and grassland fallows (Fig. 4b). While ground-dwelling spiders dominated throughout, power pole islands and grassland fallows harboured significantly more spiders preferring the herb layer than wheat fields and field margins. 
Fig. 2 Means and SE for

number of species (a), number of individuals (b), number of rarefied species (c), effective number of species (d), conservation value (e), and community weighted mean (CWM) body size (f) of spiders captured in wheat fields (W), field margins (M), power pole islands (I), and grassland fallows (F). Different letters above bars indicate significant differences among treatments (Tukey HSD posthoc tests after ANOVAs; $\mathrm{n}=9$ plots each)
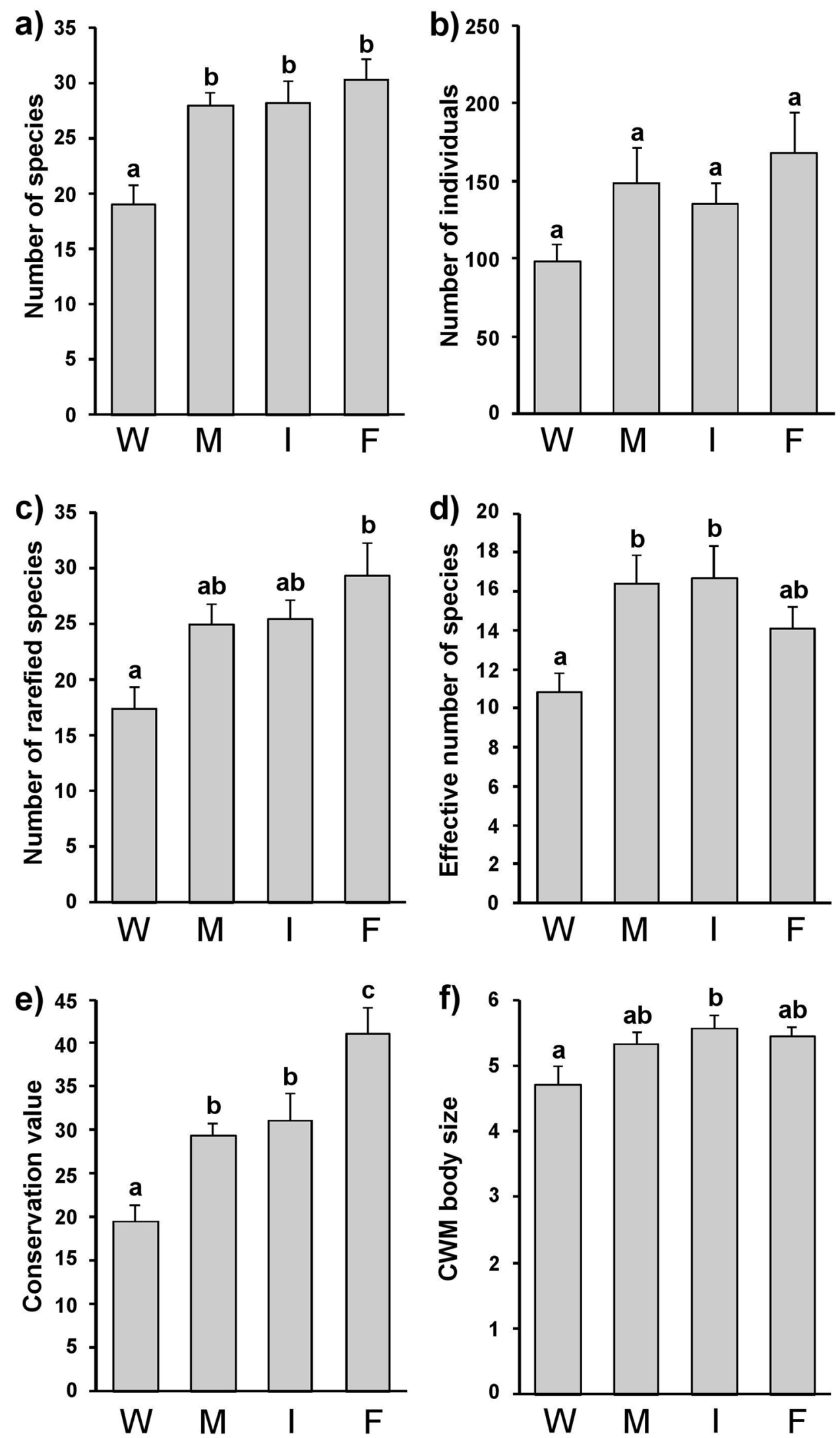
Considering the four most common species, Pardosa prativaga (Lycosidae; 517 individuals in total), P. pullata (Lycosidae; 462), Oedothorax apicatus (Linyphiidae; 278), and Tenuiphantes tenuis (Linyphiidae; 252), habitat type significantly affected the number of individuals in $P$. pullata $\left(\mathrm{F}_{3,32}=3.57, \mathrm{p}=0.025\right)$ and O. apicatus $\left(\mathrm{F}_{3,32}=3.47\right.$, $\mathrm{p}=0.027)$, while there were no significant differences for $P$. prativaga $\left(\mathrm{F}_{3,32}=1.08, \mathrm{p}=0.373\right)$ and T. tenuis $\left(\mathrm{F}_{3,32}=1.64\right.$, $\mathrm{p}=0.2$; Fig. 5). While the numbers of individuals of $P$. prativaga and $P$. pullata increased from wheat fields to grassland fallows, those of the two agrobiont species $O$. apicatus and T. tenuis decreased.

\section{Discussion}

Species richness and conservation value of spider assemblages were lower in wheat fields than in non-crop habitats. Similar patterns have been demonstrated in other studies, stressing the importance of non-crop habitats for the conservation and enhancement of spiders in agricultural landscapes (Schmidt and Tscharntke 2005; Mestre et al. 2018; Nardi et al. 2019; Pompozzi et al. 2019). Interestingly though, the three non-crop habitat types were statically indistinguishable except for conservation value, being higher on grassland fallows. The lack of differences in species richness between non-crop habitats is surprising, as grassland fallows are much larger and therefore presumably less disturbed than power pole islands or field margins. This may be due to the long history of intensive agriculture in our study area,

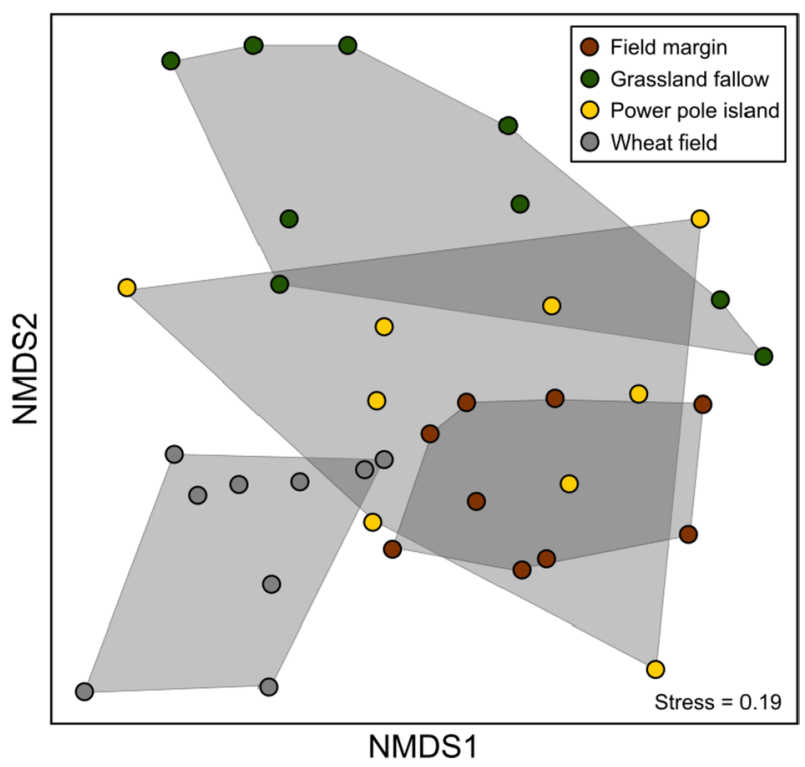

Fig. 3 Non-metric multidimensional scaling analyses (NMDS) for spider assemblages across four habitat types (based on 112 species and 4,942 individuals; $\mathrm{n}=36$ plots, 2 dimensions, Bray-Curtis distance, tries $=20$ )
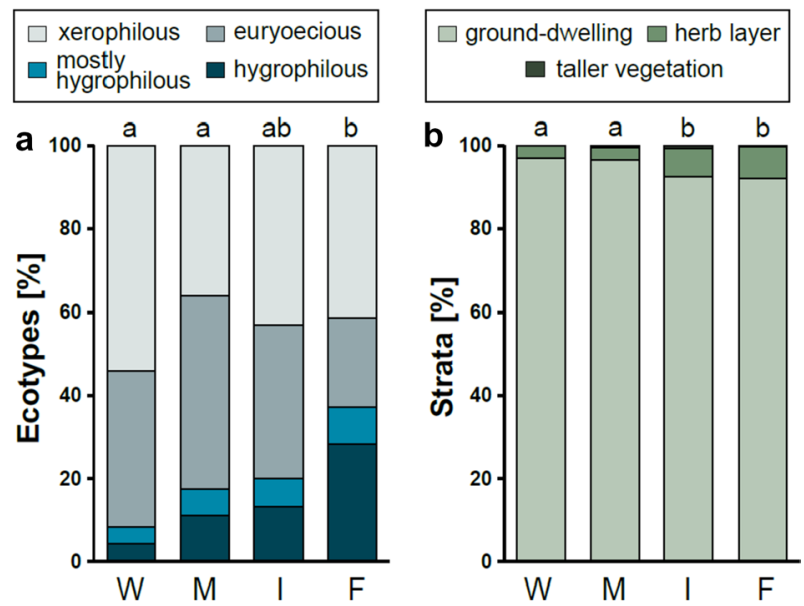

Fig. 4 Distribution of ecotypes (a; xerophilous; euryoecious; mostly hygrophilous; hygrophilous) and preferred stratum (b; ground-dwelling; herb layer; taller vegetation) of spiders captured in wheat fields (W), field margins (M), power pole islands (I), and grassland fallows (F). Given are percentages for each habitat type. Data were compiled from Platen et al. (1991) and Platen and Broen (2005). Different letters above bars indicate significant differences among treatments (Pairwise tests after PERMANOVAs; $\mathrm{p}<0.05 ; \mathrm{n}=9$ plots each)

resulting in an impoverished fauna even in such remnant sites of natural vegetation. This may also explain the overall low number of threatened species in our study. Thus, landscape-level effects may contribute to the decline of biodiversity in agricultural landscapes (Sirami et al. 2019). Fallows next to arable fields may in general have different effects on ground-dwelling predators considered, as they can serve as a sink or source (Birkhofer et al. 2018). Still, our findings demonstrate the high importance of small-scale non-crop habitats for spider conservation in agricultural landscapes. Compared to wheat fields, such habitats are relatively undisturbed and offer structurally diverse refugia with variable microhabitats that are beneficial for spiders (Clough et al. 2005; Bianchi et al. 2006).

In our study, CWM body size was larger in non-crop habitats than in wheat fields, though differences were significant between wheat fields and power pole islands only. Often, crop fields are dominated by smaller spider species, e.g. Linyphiidae, as larger species are typically less dispersive and not able to balloon (Entling et al. 2011). In general, larger species appear to be more strongly affected by agricultural practices such as ploughing (Holland and Reynolds 2003), which is why many species of the relatively large predatory Lycosidae, such as $P$. prativaga, prefer non-crop habitats (Öberg et al. 2007). Other families (e.g. Lycosidae, Gnaphosidae, Thomisidae) are favoured by litter, and therefore prefer non-crop habitats including grassland fallows (Bell et al. 2001; Clough et al. 2005).

As spider species with specific habitat requirements cannot exist in intensively managed crop fields (Knapp 


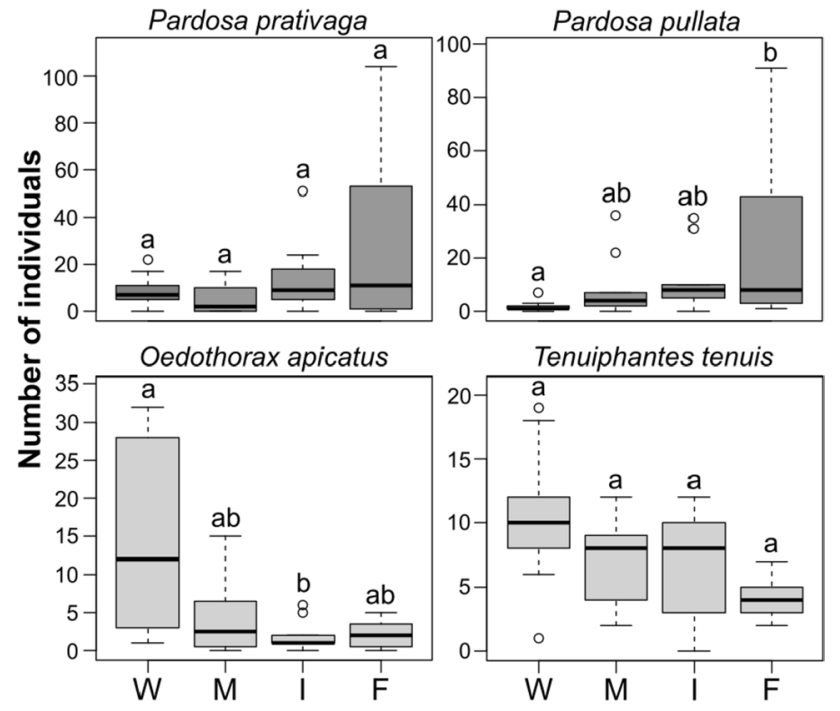

Fig. 5 Number of individuals for four common spider species in wheat fields (W), field margins (M), power pole islands (I), and grassland fallows (F). Boxplots display the interquartile range $(25-75 \%$; the box) and the median (line in the box). Whiskers represent the 1.5 times the lower or upper interquartile range and outliers are shown as dots. Different letters above bars indicate significant differences among treatments (Tukey HSD posthoc tests after ANOVAs; $n=9$ plots each)

and ̌̌ezáč 2015), these are often dominated by a few species adapted to such environments (Samu and Szinetár 2002). Such agrobionts, including O. apicatus and T. tenuis, may reach high densities in crop fields (Topping and Sunderland 1998; Gallé et al. 2018). This may explain the lack of differences in individual numbers between habitat types in our study. In particular, many Linyphiidae thrive in agricultural landscapes (Pluess et al. 2008). Members of this family can readily recolonise arable fields after disturbance due to aerial dispersal (Pfiffner and Luka 2003; Öberg et al. 2007). However, even dispersive agrobionts may need non-crop habitats, e.g. for hibernation (Thorbek and Bilde 2004; Schmidt and Tscharntke 2005), which thus comprise important source habitats (Michalko and Birkhofer 2021). Accordingly, even small-scale non-crop habitats may reach relatively high spider diversity, as these areas harbour agrobionts as well as more specialized species. Thus, proximity to non-crop habitats may increase spider diversity and thus pest control in adjacent agricultural land (Michalko et al. 2019).

Our results show that crop fields, presumably due to their aridity and periodic disturbance, were mainly dominated by xerophilous and euryoecious species, while in grassland fallows an increased proportion of hygrophilous species was found, likely due to the denser vegetation resulting in moister and cooler conditions. The spider communities from power pole islands and grassland fallows showed a higher proportion of species preferring the herb layer, which may be once again related to the more complex vegetation structure. In general, higher vegetation complexity is associated with higher species richness of spiders (Finch et al. 2008).

The above considerations suggest that species assemblages differ strongly among habitat types. This was indeed confirmed by significant differences except between field margins and power pole islands. These findings reinforce the importance of grassland fallows and small non-crop habitats for spiders in agroecosystems. They are also consistent with Feng et al. (2021) showing that older fallows, such as the long-term grassland fallows studied here, harbour more diverse communities and are particularly valuable for the conservation of specialists. In fragmented agricultural landscapes, several spider species use edge habitats for migration (Blitzer et al. 2012; Gallé et al. 2018; Nardi et al. 2019). Thus, linear field margins but also small power pole islands ('stepping stones') may improve connectivity in highly fragmented landscapes (Schirmel et al. 2016), and thereby contribute to maintaining farmland biodiversity (Bianchi et al. 2006; Hendrickx et al. 2007).

For spider surveys in agricultural landscapes, the efficiency of different sampling methods is often debated (Lang 2000; Sanders and Entling 2011). While commonly used, pitfall traps only capture the activity-density rather than the actual population density of the trapped species (Bali et al. 2019). Suction sampling may therefore give better estimates of true densities, but is largely restricted to vegetation-dwelling arthropods (Sanders and Entling 2011). Essentially, both sampling techniques complement each other by targeting different groups (Schmidt-Entling and Döbeli 2009), which is why we used a combination of both.

\section{Conclusions}

In summary, we show that small-scale non-crop habitats, such as field margins and habitat islands within wheat fields, were surprisingly effective in promoting spider diversity in an agricultural landscape. Indeed, field margins and power pole islands were as effective in promoting spider species richness as more extended grassland fallows. Nevertheless, grassland fallows had a higher conservation value and harboured different communities than field margins and power pole islands. Grassland fallows, with their structurally diverse conditions, favoured the occurrence of more hygrophilous species and ones preferring the herb layer. Notwithstanding, our results document that even small-scale non-crop habitats are important contributions to the conservation of biological diversity. To maximize overall diversity and trait composition of spider assemblages in agricultural landscapes, we propose a combination of larger long-term 
fallows and smaller non-crop habitats (such as field margins or set-aside wildflower-sown patches), as both differ clearly in species assemblages. Whether the small-scale structures involve linear field margins or small rectangular patches, e.g. areas under power poles that cannot be easily farmed anyway, seems to be of subordinate importance, as both did not differ significantly throughout. In addition, it may not be particularly important whether such structures are sown with wildflower (as is the case here for power pole islands) or not (field margins).

Supplementary Information The online version contains supplementary material available at https://doi.org/10.1007/s10841-021-00363-2.

Acknowledgements We would like to thank Roland Busch and Kim Ehringhausen for their help with the field work. We thank the local farmers and landowners for their support and for allowing us to carry out this study on their properties. The quality of this paper has been strongly improved by the constructive criticism provided by two anonymous reviewers.

Authors' contributions KF and TR designed the experiment, TR, KG and DR collected field data and identified the spiders, KF and TR analysed the data with help from KG and DR, TR and KF wrote the manuscript.

Funding Open Access funding enabled and organized by Projekt DEAL. This study was financially supported by the Ministry for Environment, Energy, Nutrition and Forest Rheinland-Pfalz through the 'Aktion Grün'

Data availability All data are provided as supplementary material.

Code availability Not applicable.

\section{Declarations}

Conflict of interest The authors declare that they have no conflict of interest.

Consent to participate Not applicable.

Consent for publication Not applicable.

Ethical approval Not applicable.

Open Access This article is licensed under a Creative Commons Attribution 4.0 International License, which permits use, sharing, adaptation, distribution and reproduction in any medium or format, as long as you give appropriate credit to the original author(s) and the source, provide a link to the Creative Commons licence, and indicate if changes were made. The images or other third party material in this article are included in the article's Creative Commons licence, unless indicated otherwise in a credit line to the material. If material is not included in the article's Creative Commons licence and your intended use is not permitted by statutory regulation or exceeds the permitted use, you will need to obtain permission directly from the copyright holder. To view a copy of this licence, visit http://creativecommons.org/licenses/by/4.0/.

\section{References}

Agrarmeteorologie Rheinland-Pfalz (2020) Langjährige Mittelwerte der Wetterstation Münstermaifeld. https://www.am.rlp.de. Accessed 10 Sep 2020

Bali L, Andrési D, Tuba K, Szinetár C (2019) Comparing pitfall trapping and suction sampling data collection for ground-dwelling spiders in artificial forest gaps. Arachnologische Mitteilungen 58:23-28. https://doi.org/10.30963/aramit5808

Batáry P, Kovács A, Báldi A (2008) Management effects on carabid beetles and spiders in Central Hungarian grasslands and cereal fields. Community Ecol 9:247-254. https://doi.org/10.1556/ ComEc.9.2008.2.14

Batáry P, Holzschuh A, Orci KM et al (2012) Responses of plant, insect and spider biodiversity to local and landscape scale management intensity in cereal crops and grasslands. Agric Ecosyst Environ 146:130-136. https://doi.org/10.1016/j.agee.2011.10.018

Bell JR, Wheater CP, Cullen WR (2001) The implications of grassland and heathland management for the conservation of spider communities: a review. J Zool 255:377-387. https://doi.org/10.1017/ S0952836901001479

Benton TG, Bryant DM, Cole L, Crick HQP (2002) Linking agricultural practice to insect and bird populations: a historical study over three decades. J Appl Ecol 39:673-687. https://doi.org/10.1046/j. 1365-2664.2002.00745.x

Benton TG, Vickery JA, Wilson JD (2003) Farmland biodiversity: is habitat heterogeneity the key? Trends Ecol Evol 18:182-188. https://doi.org/10.1016/S0169-5347(03)00011-9

Bianchi FJJA, Booij CJH, Tscharntke T (2006) Sustainable pest regulation in agricultural landscapes: a review on landscape composition, biodiversity and natural pest control. Proc R Soc B 273:1715-1727. https://doi.org/10.1098/rspb.2006.3530

Billeter R, Liira J, Bailey D et al (2008) Indicators for biodiversity in agricultural landscapes: a pan-European study. J Appl Ecol 45:141-150. https://doi.org/10.1111/j.1365-2664.2007.01393.x

Birkhofer K, Fevrier V, Heinrich A et al (2018) The contribution of CAP greening measures to conservation biological control at two spatial scales. Agric Ecosyst Environ 255:84-94. https://doi.org/ 10.1016/j.agee.2017.12.026

Blick T, Finch OD, Harms KH et al (2016) Rote Liste und Gesamtartenliste der Spinnen (Arachnida: Araneae) Deutschlands, 3. Fassung. In: Gruttke H, Binot-Hafke M, Balzer S, et al. (eds) (Red.) Rote Liste gefährdeter Tiere, Pflanzen und Pilze Deutschlands, Band 4: Wirbellose Tiere (Teil 2). Naturschutz und Biologische Vielfalt, Münster (Landwirtschaftsverlag), pp 383-510

Blitzer EJ, Dormann CF, Holzschuh A et al (2012) Spillover of functionally important organisms between managed and natural habitats. Agric Ecosyst Environ 146:34-43. https://doi.org/10.1016/j. agee.2011.09.005

Bonte D, Baert L, Maelfait J-P (2002) Spider assemblage structure and stability in a heterogeneous coastal dune system (Belgium). J Arachnol 30:331-343. https://doi.org/10.1636/0161-8202(2002) 030[0331:SASASI]2.0.CO;2

Brook AJ, Woodcock BA, Sinka M, Vanbergen AJ (2008) Experimental verification of suction sampler capture efficiency in grasslands of differing vegetation height and structure. J Appl Ecol 45:13571363. https://doi.org/10.1111/j.1365-2664.2008.01530.x

Clough Y, Kruess A, Kleijn D, Tscharntke T (2005) Spider diversity in cereal fields: comparing factors at local, landscape and regional scales. J Biogeogr 32:2007-2014. https://doi.org/10.1111/j.13652699.2005.01367.x

Critchley CNR, Allen DS, Fowbert JA et al (2004) Habitat establishment on arable land: assessment of an agri-environment scheme 
in England, UK. Biol Conserv 119:429-442. https://doi.org/10. 1016/j.biocon.2004.01.004

Donald PF, Green RE, Heath MF (2001) Agricultural intensification and the collapse of Europe's farmland bird populations. Proc R Soc B 268:25-29. https://doi.org/10.1098/rspb.2000.1325

Dormann CF, McPherson JM, Araújo MB et al (2007) Methods to account for spatial autocorrelation in the analysis of species distributional data: a review. Ecography (Cop) 30:609-628. https:// doi.org/10.1111/j.2007.0906-7590.05171.x

Entling MH, Stämpfli K, Ovaskainen O (2011) Increased propensity for aerial dispersal in disturbed habitats due to intraspecific variation and species turnover. Oikos 120:1099-1109. https://doi.org/10. 1111/j.1600-0706.2010.19186.x

Fahrig L, Baudry J, Brotons L et al (2011) Functional landscape heterogeneity and animal biodiversity in agricultural landscapes. Ecol Lett 14:101-112. https://doi.org/10.1111/j.1461-0248.2010. 01559.x

Feng L, Arvidsson F, Smith HG, Birkhofer K (2021) Fallows and permanent grasslands conserve the species composition and functional diversity of carabid beetles and linyphiid spiders in agricultural landscapes. Insect Conserv Divers. https://doi.org/ 10.1111/icad. 12520

Finch OD, Blick T, Schuldt A (2008) Macroecological patterns of spider species richness across Europe. Biodivers Conserv 17:28492868. https://doi.org/10.1007/s10531-008-9400-x

Frank T, Aeschbacher S, Zaller JG (2012) Habitat age affects beetle diversity in wildflower areas. Agric Ecosyst Environ 152:21-26. https://doi.org/10.1016/j.agee.2012.01.027

Gallé R, Császár P, Makra T et al (2018) Small-scale agricultural landscapes promote spider and ground beetle densities by offering suitable overwintering sites. Landsc Ecol 33:1435-1446. https:// doi.org/10.1007/s10980-018-0677-1

Ganser D, Knop E, Albrecht M (2019) Sown wildflower strips as overwintering habitat for arthropods: effective measure or ecological trap? Agric Ecosyst Environ 275:123-131. https://doi.org/10. 1016/j.agee.2019.02.010

Görn S, Fischer K (2011) Niedermoore Nordostdeutschlands bewerten: Vorschlag für ein faunistisches Bewertungsverfahren. Naturschutz und Landschaftsplan 43:211-217

Haaland C, Naisbit RE, Bersier LF (2011) Sown wildflower strips for insect conservation: a review. Insect Conserv Divers 4:60-80. https://doi.org/10.1111/j.1752-4598.2010.00098.x

Hendrickx F, Maelfait J, Van Wingerden W et al (2007) How landscape structure, land-use intensity and habitat diversity affect components of total arthropod diversity in agricultural landscapes. J Appl Ecol 44:340-351. https://doi.org/10.1111/j.13652664.2006.01270.x

Holland JM, Reynolds CJM (2003) The impact of soil cultivation on arthropod (Coleoptera and Araneae) emergence on arable land. Pedobiologia (Jena) 47:181-191. https://doi.org/10.1078/ 0031-4056-00181

Holland JM, Douma JC, Crowley L et al (2017) Semi-natural habitats support biological control, pollination and soil conservation in Europe. A review. Agron Sustain Dev 37:31. https://doi.org/10. 1007/s13593-017-0434-x

Hsieh TC, Ma KH, Chao A (2020) iNEXT: iNterpolation and EXTrapolation for species diversity. $\mathrm{R}$ package version 2.0.20

Huusela-Veistola E (1998) Effects of perennial grass strips on spiders (Araneae) in cereal fields and impact on pesticide side-effects. J Appl Ecol 122:575-583

Jost L (2006) Entropy and diversity. Oikos 113:363-375. https://doi. org/10.1111/j.2006.0030-1299.14714.x

Kleijn D, Kohler F, Báldi A et al (2009) On the relationship between farmland biodiversity and land-use intensity in Europe. Proc R Soc B 276:903-909. https://doi.org/10.1098/rspb.2008.1509
Knapp M, Řezáč M (2015) Even the smallest son-crop habitat islands could be beneficial: distribution of carabid beetles and spiders in agricultural landscape. PLoS ONE. https://doi.org/10.1371/ journal.pone. 0123052

Košulič O, Michalko R, Hula V (2014) Recent artificial vineyard terraces as a refuge for rare and endangered spiders in a modern agricultural landscape. Ecol Eng 68:133-142. https://doi.org/10. 1016/j.ecoleng.2014.03.030

Kovács-Hostyánszki A, Korösi Á, Orci KM et al (2011) Set-aside promotes insect and plant diversity in a Central European country. Agric Ecosyst Environ 141:296-301. https://doi.org/10. 1016/j.agee.2011.03.004

Lang A (2000) The pitfalls of pitfalls: a comparison of pitfall trap catches and absolute density estimates of epigeal invertebrate predators in arable land. J Pest Sci 73:99-106. https://doi.org/ 10.1007/BF02956438

Luczak J (1979) Spiders in agrocoenoses. Pol Ecol Stud 5:151-200

Mestre J, Schirmel J, Hetz J et al (2018) Both woody and herbaceous semi-natural habitats are essential for spider overwintering in European farmland. Agric Ecosyst Environ 267:141-146. https://doi.org/10.1016/j.agee.2018.08.018

Michalko R, Birkhofer K (2021) Habitat niches suggest that noncrop habitat types differ in quality as source habitats for Central European agrobiont spiders. Agric Ecosyst Environ. https://doi. org/10.1016/j.agee.2020.107248

Michalko R, Pekár S, Dul'a M, Entling MH (2019) Global patterns in the biocontrol efficacy of spiders: a meta-analysis. Glob Ecol Biogeogr 28:1366-1378. https://doi.org/10.1111/geb.12927

Morris AJ, Hegarty J, Báldi A, Robijns T (2011) Setting aside farmland in Europe: the wider context. Agric Ecosyst Environ 143:1-2. https://doi.org/10.1016/j.agee.2011.07.013

Nardi D, Lami F, Pantini P, Marini L (2019) Using species-habitat networks to inform agricultural landscape management for spiders. Biol Conserv. https://doi.org/10.1016/j.biocon.2019. 108275

Nentwig W, Blick T, Bosmans R et al (2020) Spinnen Europas. Version 11.2020. https://www.araneae.nmbe.ch. Accessed 27 Nov 2020

Öberg S, Ekbom B, Bommarco R (2007) Influence of habitat type and surrounding landscape on spider diversity in Swedish agroecosystems. Agric Ecosyst Environ 122:211-219. https://doi.org/10. 1016/j.agee.2006.12.034

Oksanen J, Blanchet FG, Friendly M et al (2020) vegan: community ecology package. $\mathrm{R}$ package version $2.5-7$

Östman Ö, Ekbom B, Bengtsson J, Weibull AC (2001) Landscape complexity and farming practice influence the condition of polyphagous carabid beetles. Ecol Appl 11:480-488. https://doi.org/10. 1890/1051-0761(2001)011[0480:LCAFPI]2.0.CO;2

Paradis E, Schliep K (2019) ape 5.0: an environment for modern phylogenetics and evolutionary analyses in R. Bioinformatics 35:526528. https://doi.org/10.1093/bioinformatics/bty633

Pfiffner L, Luka H (2000) Overwintering of arthropods in soils of arable fields and adjacent semi-natural habitats. Agric Ecosyst Environ 78:215-222. https://doi.org/10.1016/S0167-8809(99)00130-9

Pfiffner L, Luka H (2003) Effects of low-input farming systems on carabids and epigeal spiders - a paired farm approach. Basic Appl Ecol 4:117-127. https://doi.org/10.1078/1439-1791-00121

Platen R, von Broen B (2005) Gesamtartenliste und Rote Liste der Webspinnen und Weberknechte (Arachnida : Araneae, Opiliones) des Landes Berlin. In: Der Landesbeauftragte für Naturschutz und Landschaftspflege/Senatsverwaltung für Stadtentwicklung. Rote Listen der gefährdeten Pflanzen und Tiere von Berlin, pp 1-79

Platen R, Moritz M, von Broen B (1991) Liste der Webspinnen-und Weberknechtarten (Arach.: Araneida, Opilionida) des Berliner Raums und ihre Auswertung für Naturschutzzwecke (Rote Liste). Landschaftsentwicklung und Umweltforsch 6:169-205 
Plath E, Rischen T, Mohr T, Fischer K (2021) Biodiversity in agricultural landscapes: grassy field margins and semi-natural fragments both foster spider diversity and body size. Agric Ecosyst Environ 316:107457. https://doi.org/10.1016/j.agee.2021.107457

Pluess T, Opatovsky I, Gavish-Regev E et al (2008) Spiders in wheat fields and semi-desert in the Negev (Israel). J Arachnol 36:368373. https://doi.org/10.1636/CT07-116.1

Pluess T, Opatovsky I, Gavish-Regev E et al (2010) Non-crop habitats in the landscape enhance spider diversity in wheat fields of a desert agroecosystem. Agric Ecosyst Environ 137:68-74. https:// doi.org/10.1016/j.agee.2009.12.020

Pompozzi G, Marrero HJ, Haedo J et al (2019) Non-cropped fragments as important spider reservoirs in a Pampean agro-ecosystem. Ann Appl Biol. https://doi.org/10.1111/aab.12537

R Core Team (2020) R: A language and environment for statistical computing. R Foundation for Statistical Compuing, Vienna, Austria. https://www.R-project.org/

Ricotta C, Moretti M (2011) CWM and Rao's quadratic diversity: a unified framework for functional ecology. Oecologia 167:181-188. https://doi.org/10.1007/s00442-011-1965-5

Rischen T, Frenzel T, Fischer K (2021) Biodiversity in agricultural landscapes: different non-crop habitats increase diversity of ground-dwelling beetles (Coleoptera) but support different communities. Biodivers Conserv. https://doi.org/10.1007/ s10531-021-02284-7

Roberts MJ (1987) The spiders of Great Britain and Ireland, volume 2-linyphiidae and checklist. Harley Books, Colchester

Roberts MJ (1995) Spiders of Britain and northern Europe. Collins field guide. Harper Collins Publishers, London

Rusch A, Birkhofer K, Bommarco R et al (2015) Predator body sizes and habitat preferences predict predation rates in an agroecosystem. Basic Appl Ecol 16:250-259. https://doi.org/10.1016/j.baae. 2015.02.003

Šálek M, Hula V, Kipson M et al (2018) Bringing diversity back to agriculture: smaller fields and non-crop elements enhance biodiversity in intensively managed arable farmlands. Ecol Indic 90:65-73. https://doi.org/10.1016/j.ecolind.2018.03.001

Samu F, Szinetár C (2002) On the nature of agrobiont spiders. J Arachnol 30:389-402. https://doi.org/10.1636/0161-8202(2002) 030[0389:OTNOAS]2.0.CO;2

Sanders D, Entling MH (2011) Large variation of suction sampling efficiency depending on arthropod groups, species traits, and habitat properties. Entomol Exp Appl 138:234-243. https://doi.org/10. 1111/j.1570-7458.2010.01094.x

Schirmel J, Thiele J, Entling MH, Buchholz S (2016) Trait composition and functional diversity of spiders and carabids in linear landscape elements. Agric Ecosyst Environ 235:318-328. https://doi.org/10. 1016/j.agee.2016.10.028

Schmidt MH, Tscharntke T (2005) The role of perennial habitats for Central European farmland spiders. Agric Ecosyst Environ 105:235-242. https://doi.org/10.1016/j.agee.2004.03.009
Schmidt-Entling MH, Döbeli J (2009) Sown wildflower areas to enhance spiders in arable fields. Agric Ecosyst Environ 133:19_ 22. https://doi.org/10.1016/j.agee.2009.04.015

Seibold S, Gossner MM, Simons NK et al (2019) Arthropod decline in grasslands and forests is associated with landscape-level drivers. Nature 574:671-674. https://doi.org/10.1038/s41586-019-1684-3

Sirami C, Gross N, Baillod AB et al (2019) Increasing crop heterogeneity enhances multitrophic diversity across agricultural regions. Proc Natl Acad Sci USA 116:16442-16447. https://doi.org/10. 1073/pnas.1906419116

Statistisches Landesamt Rheinland-Pfalz (2018) Verbandsgemeinde Maifeld-Flächennutzung. http://infothek.statistik.rlp.de. Accessed 4 June 2020

Sunderland KD, Samu F (2000) Effects of agricultural diversification on the abundance, distribution, and pest control potential of spiders: a review. Entomol Exp Appl 95:1-13. https://doi.org/10. 1046/j.1570-7458.2000.00635.x

Symondson WOC, Sunderland KD, Greenstone MH (2002) Can generalist predators be effective biocontrol agents? Annu Rev Entomol 47:561-594. https://doi.org/10.1146/annurev.ento.47.091201. 145240

Thorbek P, Bilde T (2004) Reduced numbers of generalist arthropod predators after crop management. J Appl Ecol 41:526-538. https://doi.org/10.1111/j.0021-8901.2004.00913.x

Topping CJ, Sunderland KD (1998) Population dynamics and dispersal of Lepthyphantes tenuis in an ephemeral habitat. Entomol Exp Appl 87:29-41. https://doi.org/10.1046/j.1570-7458.1998. 00301.x

Tryjanowski P, Hartel T, Bldi A et al (2011) Conservation of farmland birds faces different challenges in Western and Central-Eastern Europe. Acta Ornithol 46:1-12. https://doi.org/10.3161/00016 4511 X589857

Tscharntke T, Steffan-Dewenter I, Kruess A, Thies C (2002) Contribution of small habitats to conservation of insect communities of grassland-cropland landscapes. Ecol Appl 12:354. https://doi. org/10.2307/3060947

Tscharntke T, Klein AM, Kruess A et al (2005) Landscape perspectives on agricultural intensification and biodiversity-ecosystem service management. Ecol Lett 8:857-874. https://doi.org/10.1111/j. 1461-0248.2005.00782.x

Van Buskirk J, Willi Y (2004) Enhancement of farmland biodiversity within set-aside land. Conserv Biol. https://doi.org/10.1111/j. 1523-1739.2004.00359.x

Zhang X, Axmacher JC, Wu P, Song X (2020) The taxon- and functional trait-dependent effects of field margin and landscape composition on predatory arthropods in wheat fields of the North China Plain. Insect Conserv Divers 13:328-339. https://doi.org/ 10.1111/icad.12403

Publisher's Note Springer Nature remains neutral with regard to jurisdictional claims in published maps and institutional affiliations. 